\title{
Editorial
}

\section{Gratitude: Opportunity and Contributions}

At the end of this year's ALA Annual Conference in Atlanta, my second threeyear term as editor of College $\mathcal{E}$ Research Libraries comes to a close. Thus, this is my last issue as editor of $C \mathcal{E} R L$. William Gray Potter, University Librarian at the University of Georgia, becomes the new editor with the July issue.

Having the opportunity to serve as $C E R L$ editor has been of special significance to me! I believe the other former CERL editors would echo my sentiment. There are few intellectual opportunities in professional organizations serving academic/research librarianship to make a contribution; serving as $C \mathcal{E} R L$ editor is certainly one of them.

Most editors I know tend to be intensely inquisitive; their "inflamed curiosity" contributes to their success and enjoyment. However, editors cannot treat authors like chunks of masonry to be chipped and hammered into a design; instead, an editor has to think like a Japanese gardener whose object is to make a garden look as natural as possible, but better than nature could manage without the gardener's help. Guiding and encouraging an author's work (i.e., natural growth), rather than constructing an artificial design, is a major challenge of editing.

CERL continues to enjoy top prestige as a refereed, research journal. It remains the journal of choice by promotion and tenure committees. Authors are delighted and honored to learn that reviewers have recommended their manuscripts for inclusion in the research journal. Far more manuscripts than can be published are received by the editor. Progress has been made toward getting the journal's table of contents, abstracts, book reviews, and index online. Adver-

tisers reflect confidence in CERL's reputation by continuing to purchase more space in the journal. The publication's financial health is quite sound. Each issue during the past six years has been published on time. And just as important, ACRL members continue to rank CERL as one of the best benefits they receive from belonging to that organization.

David Kaser, former CERL editor, noted that the editor has the advantage of reading and learning from all of the manuscripts received by $C \mathcal{E} R L$. Many fine manuscripts do not find their way into the journal, for one reason or other (e.g., they may not be a good fit, they may not contain the proper research methodology). My journal editing experience includes serving as editor of Library Administration \& Management and Library $\mathrm{Hi}$ Tech. For both of these respectable publications, the editor had to solicit or seek out authors to write articles. This procedure could result in getting articles that were uneven in both quality and construct. On the other hand, the surplus of manuscripts received by $C \mathcal{E} R L$ requires a stringent review process resulting in "built-in" quality control.

The most important message I want this editorial to convey is that I genuinely appreciate all the assistance so many people provided during my tenure as CERL editor.

Hugh Thompson, Director of ACRL Publications, and Dawn Mueller, Design/ Production Assistant, deserve special thanks for getting the journal published. They coordinated all of the necessary functions in getting the journal ready and 
in the hands of the readers. My assistants, June Corkin, Mary Williams, and Elizabeth Harman, were of tremendous help in editing and preparing the contents of each issue before sending the respective materials to ACRL. Fred Hay, Book Review Editor, performed outstanding service while working with the book reviewers and getting six book reviews per issue to me in a timely manner. I was fortunate in having a terrific editorial board: Jennifer Cargill, Jinnie Y. Davis, Paul Dumont, Diane Graves, Rita Jones, Thomas Kirk, Gillian McCombs, Barbara Moran, William Gray Potter, Laverna Saunders, Charles Schwartz, Paula Watson, James F. Williams II, Mark Winston, and Sha Li Zhang. Thanks, too, to the interns who did work comparable to the editorial board: Felix Eme Unaeze, Deborah Lee, Peter McCracken, Phelix Hanible, Laurel Littrell, Kurt Cumiskey, and Kathleen Carlisle Fountain. Eileen
Mcllvaine, Head of Reference in the Butler Library at Columbia University, and the reference departments at Columbia University are to be commended for their fine "Selected Reference Books" appearing in the March and September issues. Sha Li Zhang added an international dimension to the journal by generously translating annually a selected article from China's Journal of Academic Libraries for CERL. Kit Dusky could be counted on to provide the much-appreciated annual index. Much important and thoughtful work was donated by the many who reviewed books for the book review section and who reviewed manuscripts. The manuscript reviewers served an important role in sustaining and improving the quality of the journal. I am grateful for the ACRL's presidents' and others' guest editorials. To all of the foregoing contributors and the ones I did not mention, I extend a heartfelt THANKS.

DONALD E. RIGGS

Editor, College $\mathcal{E}$ Research Libraries 